\title{
FACTORS OF THE RURAL TOURISM DEVELOPMENT OF SIRINICKA ZUPA IN KOSOVO AND METOHIJA
}

\author{
Goran Maksimović1, Tatjana Ivanovićn ${ }^{2}$ Božidar Miloševićn ${ }^{3}$, Dejan Sekulićc \\ *Corresponding author E-mail: goran.maksimovic@pr.ac.rs
}

\begin{abstract}
A R T I C LE I N F O
Review Article

Received: 30 November 2019

Accepted: 11 December 2019

doi:10.5937/ekoPolj1904187M

UDC 316.334.55:338.48-44 (1-22)(497.115 Sirinićka župa)
\end{abstract}

Keywords:

agriculture, rural tourism, Sirinicka Zupa, economic effects

JEL: M21, L83, Q18

\begin{abstract}
A B S T R A C T
The authors analyse a current problem from the economic point of view on the rural development of Sirinicka Zupa and the significance of financing rural tourism. Starting hypothesis of authors is that the rural tourism directs a total agro complex towards the sustainable development of this Serbian enclave. The term "agro tourism" refers to an unbreakable interdependence between agriculture and tourism, and therefore is inevitable to solve in parallel the issues of agricultural holdings funding in the Serbian enclave Sirinicka Zupa in Kosovo and Metohija. The quality observation method, the analysis method, the synthesis method and interviews helped the authors in getting the information on business problems of agricultural holdings, and the authors were trying to give the answers, suggestions and solutions in order to help Serbian people in enclaves to engage in and develop tourism, and therefore also to survive and live on the centuries-old hearths.
\end{abstract}

(C) 2019 EA. All rights reserved.

\section{Introduction}

Agriculture in rural area is an important factor of the rural tourism development. It ensures the development of all forms of tourism in rural area, since agriculture in the urban forms of tourism represents an important economic activity, which provides food and beverage to the tourist facilities and tourists. The development of agriculture in

1 Goran Maksimović Ph.D., Associate Professor, University of Priština, Faculty of Agriculture, Kopaonička Street nn, 38219, Lešak, Serbia, +381 63419 757. E-mail: goran. maksimovic@pr.ac.rs, ORCID ID (https://orcid.org/0000-0001-5420-4293)

2 Tatjana Ivanović Ph.D., Assistant Professor, Universty of Priština, Faculty of Agriculture, Kopaonička Street nn, 38219, Lešak, Serbia, Phone +381 66005 605, E-mail: tatjana. ivanovic@pr.ac.rs,ORCID ID (https://orcid.org/0000-0001-7172-8160)

3 Božidar Milošević Ph. D., Full Professor, University of Priština, Faculty of Agriculture, Kopaonička Street nn, 38219, Lešak, Serbia, +38164 150 5273. E-mail: bozidar.milosevic@ pr.ac.rs, ORCID ID (https://orcid.org/0000-0003-4381-0276)

4 Dejan Sekulić, PhD, Assistant, University of Kragujevac, Faculty of Hotel Management and Tourism in Vrnjačka Banja, Vojvođanska bb, 36210 Vrnjačka Banja, Serbia, +38162602902, dejan.sekulic@kg.ac.rs, (https://orcid.org/0000-0002-3816-3679) 
same area depends on numerous assumptions, and especially the following ones:

- The existence of agricultural land,

- Favourable climate, pedological and other conditions for the development of agriculture,

- Favourable market-economic environment.

In recent years the tourism has become a significant segment of many countries' economies and therefore it is in the focus of numerous researches. Rural and eco-tourism are considered as a way of rural (village) revitalization and the growth of income through a supply of completely different services for tourists (Blažević et al., 2018). The rural tourism is the most important segment of a multifunctional agriculture regarding that it can create the fastest diversification and the development of rural economy. Significance of rural tourism is derived from the multiplicative influence of tourism onto the economy development. The Republic of Serbia has all necessary resources for the development of rural tourism, but its development isn't in accordance with a resource base. The most important restrictions of the rural tourism development in the Republic of Serbia are depopulation of rural areas and the lack of quality financial resources that are necessary in all segments of the rural tourist supply development. The development of rural tourism would ensure the development of agrarian entrepreneurship, rural development and the increase of employment in rural areas. Aiming to develop a domicile rural tourism in accordance with the European standards, it is inevitable to educate the entities of rural tourism, as well as defining the education financing modalities. The development of agriculture and related activities should provide the creation of new workplaces and stopping the process of rural areas demographic discharge, and also a good market for self-employment (Smith, Kubala, 2018). Rural tourism is a result of the development of cities and industry. Modern trends in tourism, in the era of increasing urbanization, environmental pollution, detachment from nature have led to an increasing orientation of tourism flows towards rural areas, rural destinations. (Lakićević, Sagić, 2019).

Interdisciplinary analysis of interdependence of these two activities (above all tourism, less agriculture) grades agro tourism as a citadel of total tourism, which is based in agriculture. The agro tourism directs an entire agro complex toward the sustainable development, the production of healthy food and its marketing. It doesn't encourage and support only the orientation of tourist activities towards an original meaning of the term "agro", but toward the sustainable integral development with the primary agriculture in the centre. Tourism meets a series of activities connected to agribusiness indirectly, through an integral development concept (Pejanović et al., 2015). End-users show increasing interest in all aspects of quality, safety and trust in organic food ingredients. If the participants in the supply chain, i.e. the producers (processors), farmers and trade companies are trying to improve the placement of these products, the supply chain management needs to focus in particular on the following indicators: quality label, product origin, composition of raw materials, freshness, price, taste, place of sale and packaging (Končar et al., 2019; Nunes et al., 2018). 
Compatibility and integrativity of natural and anthropogenic values of rural areas and tourism with all its peculiarities (tourist demand, motives, needs, etc.) point out to the necessity of calculating all functions of tourism, primarily of those social and economic (Pejanović, 2013).

\section{Materials and methods}

In this paper was perceived the current situation in rural area of Sirinicka Zupa on Kosovo and Metohija, using the quality observing method; doing business of agricultural holdings and their opportunities for being engaged in rural tourism was studied by using the analysis method; and some assumptions and possibilities for more successful work and functioning of agricultural holdings in the Serbian enclave Sirinicka Zupa on Kosovo and Metohija was given by using the synthesis method. Empirical research was realized through visits to family agricultural households, in which was determined the facts on the field in the enclave and were done some interviews with the holdings' owners. Information on problems in the business of agricultural holdings were gathered through interviews, and in this paper the authors will try to give some answers, suggestions and solutions in order to help the Serbian people in enclaves to be engaged and develop the rural tourism, and therefore their survival and life on the centuries-old hearths. The published material of the Office for Kosovo and Metohija of the Republic of Serbia and some other professional literature were used, besides the collected information in the field.

\section{Results and Discussion}

Sirinicka Zupa (Strpce municipality, around 13,000 inhabitants of Serbian nationality) occupies an area of $250 \mathrm{~km}^{2}$ with one urban and fifteen rural settlements. It represents the mountain area with a specifically indented entirety and altitude that ranges from $900 \mathrm{~m}$ in the Lepenac Valley to 2,500 $\mathrm{m}$ on the Ljuboten peak. One of five national parks, Sar Planina, which is in Sirinicka Zupa, has been founded in 1986, in area of 22,805 hectares. The National Park was established in order to preserve forest and high mountain vegetation and their habitats and population of wild flora and fauna, especially rich fauna of the daily butterflies, birds (gray hawk, western capercaillie, rock partridge), mammals (European snow vole, brown bear, wolf, chamois, etc.); area with a series of characteristic features.

The National Park Sar Planina is a cradle of Serbian spirituality, sovereignty and history. In this area lie 45 facilities of cultural heritage, and 14 among them are categorized cultural property of exceptional importance built in the period from 12th to 16 th Century. There also lie a hermitage cell of an ascetic and the monastery St. Peter Koriski from XIII Century, the church of St.Petka from the 14th Century, the church of St. Mother of God Ogiditrija from the XIV Century, the monastery Holy Trinity from the 15th Century, the remains of Dusan's city and the monastery complex Holy Archangels from the 14th Century in the vicinity of Prizren, and other cultural monuments of the greatest national importance (Cvijanović, Ružić. 2017). 
The altitude and climate conditions point out to the fact that the area of Sirinicka Zupa is extremely favourable for the development of livestock breeding, fruit- and vegetable growing. Pastures with $38.8 \%$ and meadows with $25 \%$ prevail in the structure of agricultural land in Sirinicka Zupa, which shows that the area is very favourable for the development of livestock breeding, especially sheep- and goat breeding. There could be made some preconditions for the production of top quality dairy products, and the possibility for creating a brand of Sar Planina cheese, well-known by its quality ex-Yu wide, by putting into operation the existing cheese factory, as well as by an organized supply of population with foundation stocks of sheep and goats. There are as well good conditions for the development of fruit growing, first of all berries, the agro-economic conditions of Sirinicka Zupa provide the great quality of raspberry and a high yield per area unit. Raising plantations in several localities would increase the population employment (Maksimovic et al., 2015).

Sirinicka Zupa disposes with the excellent natural conditions for agricultural production, and has a significant number of family agricultural holdings, which are engaged not only in the production of agricultural-food products, but also have real capacities for the development of rural tourism. At the same time, the agricultural holdings produce surpluses of agro-food products that are not easy to sell on the market; however, those products could be sold to tourists through meals for tourists or takeaway food. Furthermore, the rural tourism activates an unused capital, such as the important uncultivated agricultural areas, empty or semi-empty houses, stables, water mills and other facilities in rural areas. From everything the above mentioned, there could be concluded that the Serbian enclave Sirinicka Zupa has sufficient agricultural land and a sufficient number of agricultural holdings with their own land, and these are two important preconditions necessary for the development of rural tourism.

The multifunctional agriculture means the activities directed not only to the increase in production and being engaged in agriculture, but other benefits of rural life as well, such as: 1) benefit of the environmental preservation (biodiversity, flood protection, erosion, the conservation of natural landscapes); 2) benefit of providing food safety in rural areas; 3 ) development of rural areas (providing employment and connecting agriculture with other sectors); 4) social-economic benefit (preservation of the traditional rural values, cultural inheritance, promotion of the traditional gastronomy, etc.). It is about the transition from agriculture in order to produce to agriculture in order to protect.

Multifunctionality is a key word for a new EU agrarian and rural policy, which often has been connected to a rural development syntagma. Agricultural activities in this context aren't related only with land cultivation and food production, but with the environmental management, as well as with providing services to a local community and the entire society. In the basic meaning, it is not a new concept, since agriculture previously has had a multifunctional role in the economic development; however conditions nowadays have been pretty much modified. The approach to interpretation of multifunctionality is based on numerous functions of agriculture, not only in the production process, but also in other functions that are derived and entrusted by the society. That is to say, in highly 
developed European states, during past several decades, have occurred numerous entrepreneurs, who started some agricultural activity, and successively had introducing the new profitable non-agricultural activities, as well. There are many similar reviews of such rural entrepreneurship, which show that the multifunctionality concept is strictly related to presence of agricultural and non-agricultural activities within a same holding, with the joint use of the resources. In this case, the multifunctionality of agriculture represents much more than the possibility of generating extra revenue. Basically, it is about a new organizational form of entrepreneurship that connects (association) agricultural production with other activities, such as: tourism, food industry, commerce, manufacturing and service trades, cooperative system of different types, education, services, culture, health care, the preservation of landscapes and environment, land lease and house renting, and other professional activities. Thereby the rural entrepreneurship mustn't be located only in rural areas (primary rural settlements, the centres of the villages or the centres of the village communities), but in the vicinity of larger urban settlements with the potential demand for agro-food products, as well as the activities related to rehabilitation, recreation or the care on victims of the urban area social pathology (Pejanović, Vujović, 2008). The multifunctional agriculture paves the way for rural development, as well as the small agricultural and family holdings and the development of hilly-mountain area of Sirinicka Zupa.

The rural tourism, as a part of tourist supply, has the multiple implications for the integral development of agricultural production and village. In villages were built modern houses, which provided conditions for the development of rural tourism, besides other contents, surroundings, and ecological food. World Tourist Organization (WTO) was defined goals, strategy of development, organization, marketing and investments in the development of rural tourism. Tasks of the rural tourism development are based on the following facts:

- Rural tourism ensures generating revenues and workplaces,

- There should regulate the environmental protection in order to develop the rural tourism,

- $\quad$ Rural tourism revives the vital existing roles in a village and the quality of life;

- $\quad$ Rural tourism preserves the cultural heritage; and

- Affirms the market economy.

Positioning the rural tourism should be within the overall positioning of the destination. As tools for positioning the tourist destinations, and instantaneously for creating a mental image and association of destination, there are often used rural symbols, the symbols that point out to rural activities including the symbols of nature and culture, the symbols of rural accommodation including farms, traditional villages, as well as the examples of rural architecture, while the human symbols reflect soul and heart of the rural and multifunctional surrounding (Maksimović et al., 2016). 
The rural tourism vision is based on the principles of alternative mass market tourism, sustainable approach to economic development, joint strategy for planning the partnership of private and public sector, harmonization of standard in tourism, balance among the forces of progress, stagnation and employment. Strategic principles of the rural tourism are:

- Good organization and cooperation,

- Connecting and the cooperation network among participants in rural tourism,

- Legal approach to natural and cultural advantages of destinations, and

- Group of companies in a village for making a critical mass of facilities.

Efficient organization of the rural tourism comprises the municipal organizations, accommodation services providers, other tourist services providers and a local-regional administration. It is responsible for determining vision and strategy, organization and maintaining a classification system, marketing of the rural tourism by fields, providing services to the rural tourism carriers, exchange of experiences, training, financing and lobbying with government and non-government organizations. Training and education are the key conditions for the development of rural tourism and implies training of trainers, training of service providers in the rural tourism (care of the consumer), knowledge of foreign languages, standardization of products, understanding the partner needs, knowledge on a product, elemental marketing and internet training of the local government officials. Besides investments, it is important to invest in human resources. Legal regulatory rules of the environment protection and legal regulations are important for the development of rural tourism (agro tourism). Farmers are good hosts and ready to accept and host tourists. The modern marketing concept is necessary in the presentation of rural supply with all activities (contents) and a competitive price of accommodation, including all sanitary measures. Integral relation between tourism and agriculture is based on satisfying the needs as a part of a wide list of tourist consumption, creating possibilities for better and more complete use of labour in the rural environment and dynamizing the development of rural areas. A share of agrarian and final products is increasing in a value of hospitability services together with the development of tourism and the increase of service quality. Through the valorisation of the attractive rural landscapes, tourism represents an important factor of the under developed areas development, supplementary occupations and extra revenues of rural population. It promotes the production and the quality of products, affects demand and changing the culture of rural life. Tourists are supplied with food from this rural area, there increases the employment, creates conditions for the rural development and therefore increase the standard of living of the domicile population. From the social point of view, the rural tourism is a dam for migrations of Serbian population from Sirinicka Zupa to the central Serbia. Tourism has an effect on the spatial and urban organization, the increase in educational-cultural level of rural population. From the consumption point of view, tourism affects the development of agrarian production, the employment in agriculture 
and rural area, the life and working conditions in the village. The village is involving in a tourist supply through vacations in the rural environment, together with engaging households in tourist services, hunting tourism with the accommodation and food services, fishing with extra services, tourist manifestations organization in the scope of agriculture-harvest and events. There is a direct demand of a tourist economy for the agrarian products, which has an effect on a volume, type and quality of products, as well as a higher income of farmers. In other words, tourism is a great consumer of agrarian products and it affects the stable development of agriculture. It is also an additional activity of agriculture through land lease for the construction of facilities, additional employment in tourism, and provides accommodation and food in the village. Tourism has an effect on the quality of life in the village, as well. The rural tourism effects are relevant from the aspect of a total rural development, extra revenues, employment and raising general living culture, the development of service activities and home craft. The rural tourism development requires also more significant investments in facilities and equipment, infrastructure and sports content. Rural, spa, mountain, health, sports and transit tourism have perspective and influence on the development of ecological food production, higher incomes, more quality life and development. It is necessary to develop eco-tourism (valorisation of the area ecological values), agro-tourism (participation in agricultural activities and food), agro-bio-tourism (organic food, education, food, vacation), recreational, health and educational tourism within the rural development, together or separately from the rural tourism. The key factors of tourism influence on agriculture are: in production, tourism represents an additional activity to agricultural production; furthermore, it is the agrarian products' market and a factor of developmental trends in agriculture; it strengthens the economic basis of development and rural standards. In non-economic field, tourism is a factor of stopping migrations, and it affects the growth of educational and cultural level in the village, urbanization and farmerization (Pejanović, 2013).

\section{Rural tourism in the concept of economic, regional and economic development}

Therefore the rural tourism is a part of the multifunctional agriculture concept, i.e. observed in a broader sense, a concept of the integral rural development. The rural tourism is primarily a part of the tourist activity, which comprises totality of relations and businesses related to traveling and temporary stay of people outside their residences, due to vacation, entertainment, etc. Tourism can be: rural, hunting, health, entertaining, cultural, sports, excursion, and resort-oriented; season and off-season tourism; domestic, foreign and border tourism; individual and collective, etc. It is important for the local and national economy, because it generates revenues. The development of rural tourism leads to a faster improvement of all related activities (commerce, industry, agriculture, utility services, cultural institutions, home craft, and hospitability). Organizationally simplification of the regional tourist brands, by highlighting the wellknown geographical terms, differentiated positioning of clusters in the market, more efficient operation on attractiveness, marketing, productivity and managing destinations would be achieved by forming clusters, as the widest functionally-market and spatial 
entirety of tourism in the Serbian enclave Sirinicka Zupa (Maksimović et al., 2015). Disposition of the characteristic clusters in the Republic of Serbia anticipated by the strategy is not based on the administrative borders, which currently exist within the country, but first of all, it is based on the rational strongholds in different forms of the economics of experience that can be developed in some regions of the country (Cvijanović et al., 2018). The goals of a cluster's members, farmers, suppliers, and other entrepreneurs and institutions in the enclaves, which unite resources and thereby make and increase the competitive capacities on the market, are achieved by improving and developing clusters and their activities. Personnel, finances (access to favourable credit sources) and the possibility of joint ventures realization, raw materials, new knowledge and technology are something they try to make up by joining the clusters. There are realized as well the wider economic, social and general social interests of the Serbian community, such as: growth of employment in rural areas, stimulation of youth to stay in Kosovo and Metohija, as well as the increase in productivity and improvement of agricultural production and the environment preservation and other aspects in rural areas (Živković, Maksimović, 2018).

Tourism is of utmost interest for the employment of population. This is why all countries, especially the ones that have favourable natural conditions for the tourism development (Serbia), establish special organizations (educational, tourist, etc.) and agencies, which deal with the improvement of tourism. There is continuously monitored the tourist demand, tourist supply, tourist policy, and carry out the scientific research of a tourist market, due to permanent improvement of tourism, anticipation of trends and realistic expectations. We will pay attention briefly to the basic issues of rural tourism. A tourist destination is defined spatial entirety, which has capacity for the stay of tourists, but also the attractive power to them. A content of every tourist destination should be adjusted, as much as possible, to requirements and needs of tourists for the usable and aesthetic values. Creating the tourist destination supply starts from the insight and analysis of advantages and weaknesses of every destination. The insight of Sirinicka Zupa natural attractions like: rural environment, rivers, springs, caves, mountains, favourable climate, flora and fauna diversity ensures the assessment of advantages and weaknesses of the tourist destination. The tourist destinations have their cultural, natural, demographic, economic and architectural specificities. Attractiveness of some destinations depends however on the social potentials for the development of tourism, such as the way of living and amenities of population, folklore, but also economic development and stability, as well as of sports, culture, science and education. The tourist values are consisted of tourist services with included various types of goods and the specific values of a country, and these are ecologically preserved nature, cultural-historical heritage, safety of the political and social-economic system, infrastructure (roads, hospitability, commerce, craft, health care, tourist agencies, utilities, science etc.), which by creates preconditions for satisfying the tourist demand. Most of the tourist supply segments have been non-transferable, cannot be multiplied or spent, and only get the market valorisation in tourism (e.g. climate, nature, cultural heritage). The tourist demand 
is an amount of tourist values, services and goods that tourists are willing to accept according to a certain price level. A base for defining the tourist demand represents a combination of tourist needs to travel, rest and getting to know new destinations, people and communication. It is possible to transform need into a real tourist demand only if it is completed with the effective purchasing power of population, as a crucial assumption of inclusion in the tourist market. The basic characteristics of the tourist demand are: seasonal character and a high level of flexibility, which causes are often uneconomical. As regard to economic criteria, demand mainly depends on: available income of individual or household, prices of tourist services, tourist marketing, as well as of the individual reasons, i.e. desires and preferences of a man, satisfaction and fulfilment of expectations, etc. It is about a special market type (sui generis), not after the constitutional elements (supply, demand, objects of exchange - services and prices), but after interaction among these elements, from which arise numerous specificities (for example, very high heterogeneity in demand, its expressed flexibility to changes of prices, income and promotion, mobility, expressed heterogeneity of supply and its rigidity, seasonal business character and other characteristics: superposition of process and consumption, impossibility of storage, advance sale of product, etc.). Tourist marketing is a significant activity within the tourist market. The marketing task in tourism, which is becoming more important, is making and keeping the competitive advantages of tourist companies, organizations, agencies, as well as tourism as an economic branch. Staring from the economic and social importance of tourism, a state in high developed countries tends to formulate an adequate tourist policy, as a base for the development of tourism. Affirmation of the tourist policy in many countries has provided a successful development of tourism, which should be a guidepost for our country as well. Thereby, the development of rural tourism, as a segment of tourism, doesn't get in the way of the agricultural development, but it surely supplements it.

The rural tourism increasingly covers some regions, and therefore it becomes a regional macro-economic challenge. Problem is however that the rural tourism impact on the regional development neither has been sufficiently drawn-out, nor methods for the successful quantification of the impact have been determined. Hence, the influence of rural tourism on the regional development isn't yet systematically followed, there is no necessary indicators that can support the verification, so there is hard to determine the total results of tourism impact on the development of the specific region. If the rural tourism had influenced the change of economic image of some regions, we could see from a fact that it wasn't only economic, but also sociological, geo-strategic and political category. Nowadays, the rural tourism represents a part of unique function of the socio-economic system, which furthermore means that it activates all parts of a secondary products of other branches and activities in making the most quality rural tourist product. Experiences of rural and regional development within the EU shows that the development of rural tourism provides: stabilisation of the total regional development, complete valorisation of natural and anthropogenic values of rural areas, preservation of tradition, culture and recognizable identity of rural communities, 
optimisation of relations between rural and urban entireties of the region, increase of the competitive ability of the region as a tourist destination. Parallel development of all economic activities of the region, the rural space itself and management efforts to consider a tourist product from rural areas an adequate integral part of the total regional gross domestic product (GDP).

The EU satisfies the following, by accepting the challenges of the rural tourism regional development in high-developed countries: its identity (economic, social, political and ecological), establishes optimal relationships of urban and rural areas (since majority population of urban areas in our country originates from a rural setting, there accomplishes so called "going back to the roots"). Economic redistribution of the tourist product's secondary parts, social stability, creating the adequate tourist culture in accordance with the international codes of conduct, compatibility in all segments of the social-economic development, achieving full employment, as surplus in living space, as well as surplus in labour (primarily women), determining the tourist accommodation capacities in accordance with disposable resources of the region. Rural population within the EU increasingly accepts tourism as one of the sustainable development strategies of a local community. The rural tourism in those areas not considered as the tourist destinations in traditional sense, has developing twofold; on the one hand, it arises as a result of entrepreneurial activities directed to the attraction of tourists, and on the other hand, the increase in number of tourists in rural areas leads to generating demand for tourist services, which leads to the increase of entrepreneurial activities on a local level.

Adequate quality and quantity valuation of interdependence and connectivity between the rural development and tourism is determined through an analysis of economic effects of tourism and partly mutual economic effects. As the direct ones, there are manifested the following influences of tourism on agriculture: higher production and higher sales of agricultural products, higher salaries, new workplaces, the development of underdeveloped and poorly developed areas, stopping emigrations from some villages and municipalities due to the lack of job, the stimulation of the natural population increase, protection and valorisation of the cultural-historical values (monuments, monasteries, galleries etc.). Tourism, through the indirect economic impacts on agriculture, encourages directly also a series of other activities in a segment of the wider economic system: including economy into the international division of labour, the general economic and cultural development, social and pension policy, etc. The economic effects for rural area of Sirinicka Zupa are very important and numerous: development of many abandoned rural communities by valorising neglected properties and houses in the village. The essence of the supply in rural areas is staying in renovated traditional village houses, with the possibility of independent preparation of food, getting to know the traditional cultural values and customs, and everything in the ecologically healthy environment. Accommodation and nutrition of tourists in this way are much more attractive, economically cheaper and at the same time healthier than the usual hotel accommodation and food. It means that the independent food preparation in rural houses unites the classical accommodation and food services into one, unlike the classical hospitability services. Furthermore, this form 
of tourism in rural areas would be realised during the whole year, unlike the seasonal character of other selective forms of tourism. As a special significance of rural tourism and its advantage comparing all other forms of tourism can be its non-seasonal character, i.e. functionality of 365 days. Tourism encourages continuously a series of other activities in the rural area, which participate directly or indirectly in providing services to tourists (traffic, commerce, manufacturers of food and beverages, construction and other activities that take part in supply).

The development of tourism encourages or has an effect on the macro-state level: impact on a balance of payment of a country, influence on the population employment and life standard, incentive of the other economic activities development included in the tourist economy. Extensive separation of the tourist demand and supply of the specific rural area or destination points out to the significance of organizational activities in the sense of establishing efficient relationships between the carriers of demand and supply. Cases in practice confirm that volume of a tourist turnover and consumption depend on the efficient organization of rural development and tourism in general, and especially in the sense of establishing favourable relationships between the carriers of tourist demand and supply (Pejanović, 2013).

All forms of rural tourism in the area of Sirinicka Zupa represent a chance to employ the unemployed people, as well as many displaced population (after the war in 1999 and 2004) from other regions in Kosovo and Metohija in Sirinicka Zupa, who seek for their chance in agricultural production, tourism, trade and crafts and other activities that have the comparative advantage in regard to other areas must base their activity on the modern marketing activities, i.e. to manufacture those products and services desirable in the market, in order to be successful in their new engagements.

\section{Conclusions}

The development of rural tourism in the Serbian enclave in Sirinicka Zupa is both opportunity and necessity, having in mind all disposable resources, and by realizing the economic under development, it is inevitable to implement the project "Rural tourism in terms of the regional development". Rural tourism would provide the diversification of rural economy, additional incomes to rural population, the decrease of unemployment, as well as reducing differences in the economic development of rural and urban areas. Tourism is the opportunity for agricultural holdings, which are mainly engaged in selling the primary (unprocessed) agricultural products, to sell food products to tourists on their own holdings. Education of hosts and members of holdings and the good marketing would provide tourists the stay in nature in the rural environment of Sirinicka Zupa: possibilities for walking, recreation, hunting and fishery, picking medicinal herbs and forest fruits. Tourists can be involved, at their own request, in performing farm works, preparing fruit juices and jams of fresh picked organic fruits. It is necessary to finance the development of rural tourism and comprise: infrastructure, personnel, tourist activities, and is necessary to apply the adequate standardization and categorization of services, especially the adequate conditions for accommodation, promotions and sales 
channels of agro-tourist products in the Republic of Serbia, countries in the region and in this way to support the Serbian population in Kosovo and Metohija; there would be stopped migrations through creating elemental conditions for the general, a much higher standard of Sirinicka Zupa rural population.

\section{Acknowledgements}

The paper is part of the research at the project 179001: "Organizational and information support to the system of quality management as a key factor to increase the competitiveness of national companies and their rapid entering the global and EU markets", financed by the Ministry of Education, Science and Technological Development of the Republic of Serbia.

\section{Conflict of interests}

The authors declare no conflict of interest.

\section{References}

1. Blažević, M., Peters, K., \& Chen, G. (2018). Developing rural tourism in minority ethnic villages: Zlot and Xiaocang She Ethnic Township. Hotel and Tourism Management, 6(2), 71-78. https://doi.org/10.5937/menhottur1802079B

2. Cvijanovic, D., \& Ruzic, P. (2017). Rural Tourism. University of Kragujevac, Faculty of Hotel management and Tourism in Vrnjacka Banja.: Cvijanovic, D., \& Ruzic, P. (2017). Ruralni turizam. Univerzitet u Kragujevcu, Fakultet za hotelijerstvo i turizam u Vrnjackoj Banji, Vrnjacka Banja].

3. Cvijanovic, D., Vujovic, S., \& Maksimovic, G. (2018). Mechanisms and specifics of the functioning of the supply and demand in the tourism market, Developmental Academy of Agriculture of Serbia. [in Serbian: Cvijanovic, D., Vujovic, S., \& Maksimovic, G. (2018). Mehanizmi i specificnosti funkcionisanja ponude i traznje na turistickom trzistu, Razvojna Akademija poljoprivrede Srbije, Beograd].

4. Končar, J., Grubor, A., \& Marić, R. (2019). Improving the placement of food products of organic origin on the AP Vojvodina market. Strategic Management, 24(3), 24-32.

5. Lakićević, M., \& Sagić, Z. (2019). Accommodation capacities and their utilization in the function of tourism development: Case of Ivanjica. Ekonomika, 65(3), 77-88.

6. Maksimović, G., Milosević, B., Babić, V. (2015). Agricultural cooperatives as development factor of Serbian Enclaves in Kosovo and Metohija. Agrieconomica, 44, 136-148.

7. Maksimović, G., Milošević, B., Milenković, M., \& Đorđević, Lj. (2015). Clusters as a factor of Serbian enclaves subsistence in Kosovo. Agro-knowledge Journal, $16(2), 263-272$. 
8. Maksimović, G., Milošević, B., \& Jovanović, R. (2017). Research of consumers' attitudes on the organic food consumption in the Serbian enclaves in Kosovo. Economics of Agriculture, 64(3), 987-1003.

9. Maksimović, M., Urošević, S., \& Karabašević, D. (2016). The positioning strategy of rural tourism on Stara Planina. Hotel and Tourism Management, 4(2), 112-121.

10. Nunes, F. G., Martins, L., \& Mozzicafreddo, J. (2018). The influence of service climate, identity strength, and contextual ambidexterity upon the performance of public organizations. The influence of service climate, identity strength, and contextual ambidexterity upon the performance of public organizations, (31), 6-20.

11. Pejanovic, R., \& Vujovic, S. (2008). Rural development and agrotourism, Agrieconomica, 38. 5-14.

12. Pejanović, R. (2013). Rural Development and Agritourism. Tours in Agricultural and Rural Economics. Faculty of Agriculture, Novi Sad. [in Serbian: Pejanović, R. (2013). Ruralni razvoj i Agroturizam. Ogledi iz agrarne i ruralne ekonomije. Poljoprivredni fakultet, Novi Sad, 269-279].

13. Pejanović, R., Maksimović, G., Radović, G., \& Njegovan, Z. (2015). Rural Development and Agrarian Entrepreneurship - Potentials for Family Business. Proceedings - How to increase employment in Serbia. University of Novi Sad, 99-109 [in Serbian: Pejanović, R., Maksimović, G., Radović, G., \& Njegovan, Z. (2015). Ruralni razvoj i agrarno preduzetništvo - potencijali za porodičan biznis. Zbornik radova - Kako povećati zaposlenost u Srbiji. Univerzitet u Novom Sadu, 99-109].

14. Radović, G., Pejanović, R., \& Njegovan, Z. (2015). Rural tourism as a factor in the development of agrarian entrepreneurship and employment growth in the Republic of Serbia. Proceedings - How to Increase Employment in Serbia, University of Novi Sad, 109-117, [in Serbian: Radović, G., Pejanović, R., \& Njegovan, Z. (2015). Ruralni turizam kao faktor razvoja agrarnog preduzetništva i rasta zapošljavanja u Republici Srbiji. Zbornik radova - Kako povećati zaposlenost u Srbiji, Univerziteta u Novom Sadu, 109-117].

15. Smith, S., \& Kubala, P. (2018). Social Justice in the Workplace: Are On-Demand Companies Exploiting Current Regulatory Ambiguities and Workforce Precarity?. Psychosociological Issues in Human Resource Management, 6(1), 166-171.

16. Živković. B., \& Maksimović. G. (2018). Strategic managment of rural tourism development. International Scientific Conference - Thematic Proceedings: Tourism in function of development of the Republic of Serbia, 556-574. 
